\title{
Efficient Synthesis of New $\alpha-\beta$-Unsaturated Alkyl-Ester Peptide-Linked Chiral Amines ${ }^{\dagger}$
}

\author{
Oscar Villanueva-Kasis 1,2, Denisse A. de Loera ${ }^{2}$, Sandra L. Castañón-Alonso ${ }^{1}$, \\ Armando Domínguez-Ortiz ${ }^{1}$, Leticia Lomas-Romero ${ }^{1}$, Ilich A. Ibarra ${ }^{3, *}$, \\ Eduardo González-Zamora ${ }^{1, *}$ and Alejandro Islas-Jácome ${ }^{1, *}$ \\ 1 Departamento de Química, Universidad Autónoma Metropolitana-Iztapalapa, San Rafael Atlixco 186, Col. \\ Vicentina, C.P. 09340 Iztapalapa, Ciudad de México, México; osk.quim@hotmail.com (O.V.-K.); \\ scastanon@xanum.uam.mx (S.L.C.-A.); doar@xanum.uam.mx (A.D.-O.); 1lr@xanum.uam.mx (L.L.-R.) \\ 2 Facultad de Ciencias Químicas, Universidad Autónoma de San Luís Potosí, Av. Manuel Nava 6, Zona \\ Universitaria, C.P. 78210 San Luis Potosí, S.L.P., México; atenea.deloera@uaslp.mx \\ 3 Laboratorio de Fisicoquímica y Reactividad de Superficies, Instituto de Investigaciones en Materiales, \\ Universidad Nacional Autónoma de México, Circuito Exterior S/N, Ciudad Universitaria, C.P. 04510 \\ Coyoacán, Ciudad de México, México \\ * Correspondence: argel@unam.mx (I.A.I.); egz@xanum.uam.mx (E.G.-Z.); aij@xanum.uam.mx (A.I.-J.); \\ Tel.: +52-55-5622-4595 (I.A.I.); +52-55-5804-4913 (E.G.-Z. \& A.I.-J.) \\ + Presented at the 22nd International Electronic Conference on Synthetic Organic Chemistry, 15 \\ November-15 December 2018; Available Online: https://sciforum.net/conference/ecsoc-22. \\ Published: 14 November 2018
}

\begin{abstract}
Four new $\alpha$ - $\beta$-unsaturated alkyl-ester chiral amines were synthesized in excellent yields (77-95\%) via peptide couplings from their corresponding $\alpha$ - $\beta$-unsaturated alkyl-ester anilines and $\mathrm{N}$-Boc protected chiral aminoacids. To our delight, these polyfunctionalized compounds are being used as starting reagents in Ugi-type three-component reactions (Ugi-3CR) together with alkyland aryl-aldehydes and a chain-ring tautomerizable amino acid-containing isocyanide to synthesize novel oxazole-based macrocycle precursors. Thus, the aim of this communication is to show our most recent results of the synthesis and use of new and complex chiral amines to assemble macrocyclic polypeptides with potential application in medicinal chemistry, such as the post-surgical antibiotic Vancomycin.
\end{abstract}

Keywords: chiral amines; $\alpha$ - $\beta$-unsaturated alkyl-ester anilines; peptide synthesis; $N$-Boc protection-deprotection; multicomponent reactions; Ugi-3CR; chemoselective reductions

\section{Introduction}

Multicomponent reactions (MCRs) are highly convergent one-pot processes [1] in which three or more reagents are combined sequentially to construct complex products [2] with most atoms present in the starting materials [3]. Thus, MCRs are commonly used to synthesize compounds with potential applications in various fields of science and technology. However, most of the MCR's synthetic targets are prepared considering their potential pharmaceutical properties [4], from a combinatorial chemistry [5], diversity-oriented synthesis [6] or target-directed synthesis [7] approaches. In this context, we recently reviewed the use of MCR-based strategies to synthesize novel bioactive products, for example, pharmacophore-containing polyheterocycles [8]. Particularly, there are reports describing the use of MCRs to synthesize-often efficiently-series of new/novel sugar-containing products [9], peptide-based compounds [10], macrocycles [11], macro-polyheterocycles [12], as well as polycyclic analogues of natural products [13], all of them using exotic amines as starting reagents. 
Thus, the aim of this communication is to show our most recent results about the synthesis of the four new $\alpha$ - $\beta$-unsaturated alkyl-ester chiral amines $\mathbf{2 a - d}$, which have begun to be used as precursors of the chiral macrocyclic polypeptides 1, compounds with potential application in medicinal chemistry (Scheme 1). It is worthy to note that the amines $\mathbf{2 a}-\mathbf{d}$ have not been synthesized or isolated anywhere. In the same way, the use of chiral amines as starting reagents for Ugi-type reactions (or other MCRs) has been little reported in comparison to non-chiral amines [14].

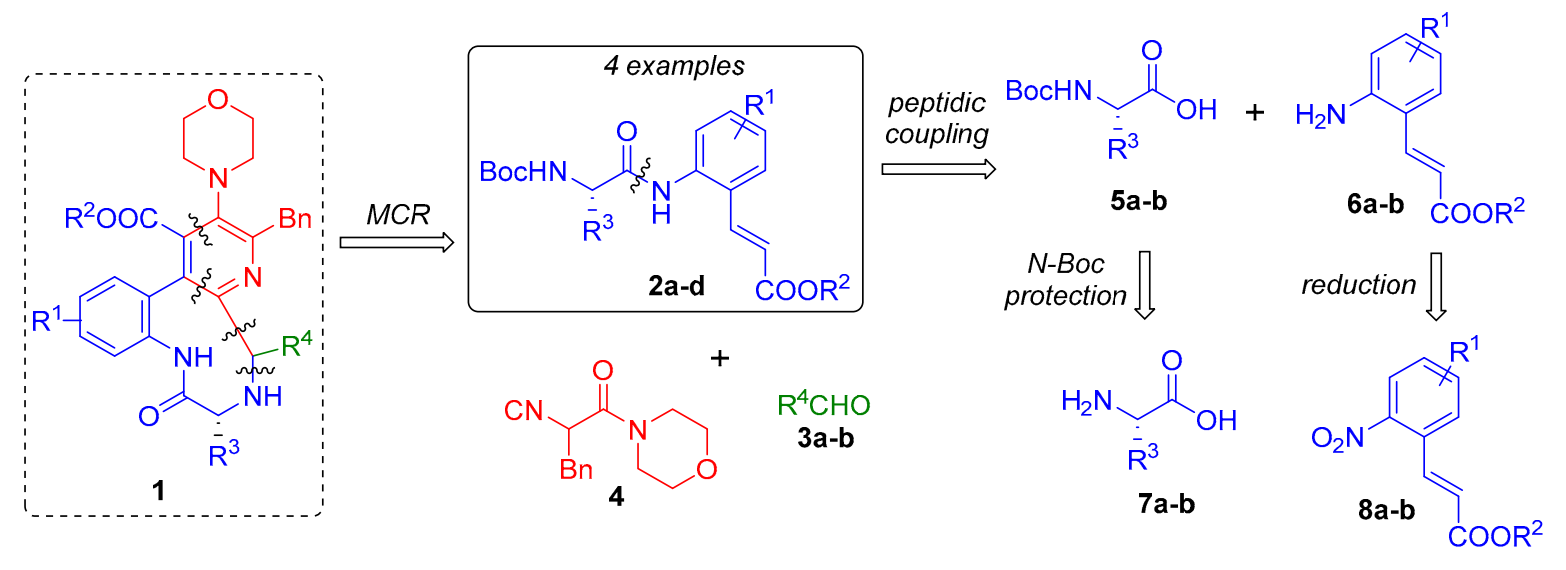

Scheme 1. Retrosynthetic analysis.

As direct background of the results we communicate here, in collaboration with Zhu and co-workers (2001), eight new oxa-bridged 5-alkyl-benzo[f][1,7]naphthyridines $12\left(\mathrm{R}^{3}=\right.$ alkyl) were synthesized efficiently via an Ugi-3CR/intramolecular aza Diels-Alder cycloaddition [15] (Scheme 2). Then, again in collaboration with Zhu and co-workers (2007), the optimal conditions to aromatize the oxa-bridged 5-alkyl-benzo[f][1,7]naphthyridine system to synthesize the 5-alkyl-benzo[f][1,7] naphthyridines $13\left(\mathrm{R}^{3}=\right.$ alkyl) were investigated [16] (Scheme 2). Finally, in 2018, we reported the synthesis of eight new oxa-bridged 5-aryl-benzo[f][1,7]naphthyridines $12\left(\mathrm{R}^{3}=\right.$ aryl $)$ and their corresponding aromatic analogues $13\left(\mathrm{R}^{3}=\right.$ aryl) via a coupled cascade process Ugi-3CR/intramolecular aza Diels-Alder cycloaddition/aromatization [17] (Scheme 2).

i) Ugi-3CR / intramolecular aza Diels-Alder cycloaddition, ii) aromatization

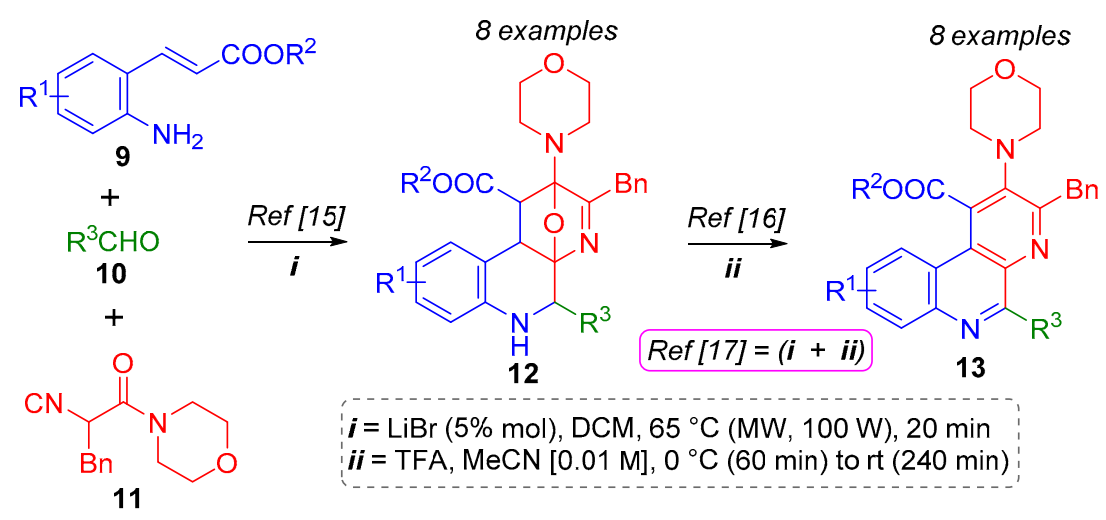

Scheme 2. Own previous work.

Then, based on our previously reported methodologies, we hypothesized that by placing smartly $\mathrm{N}$-Boc protected chiral aminoacids in the amine moiety $\mathbf{9}$, it would be possible to synthesize the chiral peptidic macro-polyheterocycles with potential application in medicinal chemistry.

\section{Results and Discussion}

To prepare the desired $\alpha$ - $\beta$-unsaturated alkyl-ester chiral amines $\mathbf{2 a}-\mathbf{d}$, it was necessary first to synthesize the $N$-Boc protected amino acids $5 \mathbf{a}-\mathbf{d}$ from its corresponding chiral amino acids $7 \mathbf{a}-\mathbf{b}$, as 
well as the ortho-aminocinnamates $\mathbf{6 a - b}$ from their corresponding ortho-nitrocinnamates $\mathbf{8 a - b}$. Thus, the L-phenylalanine and L-alanine were $\mathrm{N}$-protected following the protocol described by Ragnarsson and co-workers [18] using di-tert-butyl dicarbonate $\left(\mathrm{Boc}_{2} \mathrm{O}\right)$ in basic conditions for 48 hours at room temperature to give the $N$-Boc protected amino acids $\mathbf{5 a - b}$ in $58 \%$ (phe) and 89 (ala) yields, respectively (Scheme 3). It is worthy to note that both amino acids 5 were used for further peptidic couplings, and for this reason, they had to be $N$-protected to avoid the inherent formation of by-products just under peptidic coupling conditions. Additionally, the $\alpha$ - $\beta$-unsaturated ortho-nitrocinnamates $\mathbf{8} \mathbf{a}-\mathbf{b}$ were reduced chemoselectively via a modified version of the method reported by Porter and co-workers [19] using Fe[0] and $\mathrm{FeSO}_{4}$ in aqueous media for 12 hours at room temperature to afford the $\alpha$ - $\beta$-unsaturated ortho-aminocinnamates $6 \mathbf{a}-\mathbf{b}$, yielding $88\left(\mathrm{R}^{2}=\mathrm{Et}\right)$ and $89 \%\left(\mathrm{R}^{2}=\mathrm{Me}\right)$ (Scheme 3). Then, having in hand the compounds 5 and $\mathbf{6}$, peptidic couplings were carried out to afford the $\alpha$ - $\beta$-unsaturated alkyl-ester chiral amines $2 \mathbf{a}(77 \%), 2 \mathbf{b}(95 \%), 2 \mathrm{c}(86 \%)$, and 2d (94\%), which were excellent yields considering: $i)$ that the formation of by-products were kept to a minimum, ii) asymmetric centers were retained, and iii) the molecular complexity of the final products (Scheme 3). As seen, better yields were observed for the L-phenylalanine derivatives $\mathbf{2 b}$ (95\%) and $\mathbf{2 d}(94 \%)$ (Scheme 3).

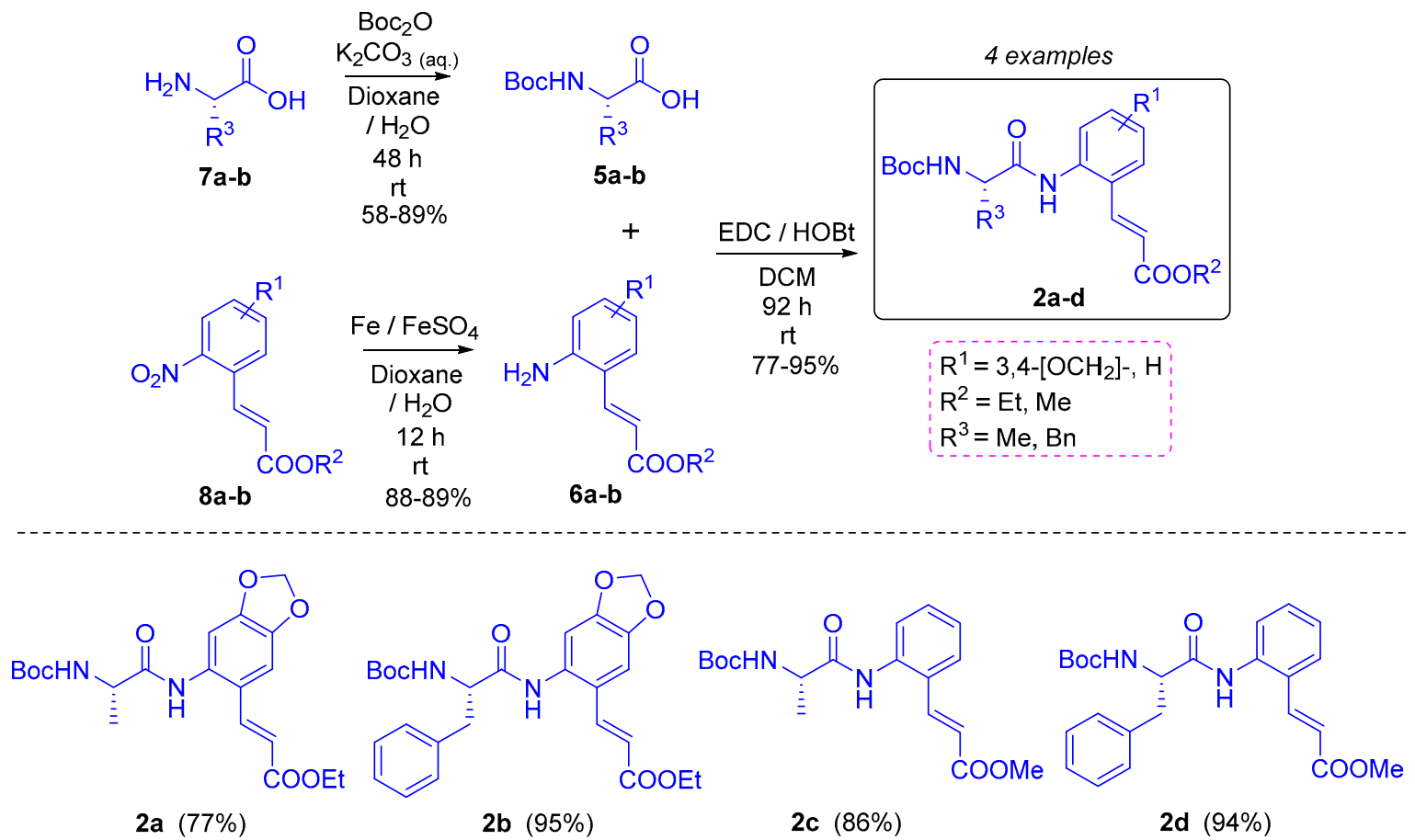

Scheme 3. $\alpha$ - $\beta$-unsaturated alkyl-ester chiral amines.

The products 2a-d were characterized by their physicochemical properties, as well as by the classical spectroscopic techniques (see the experimental part for further details). The ethyl (S,E)-3-(6-(2-(tert-butoxycarbonyl)amino)propanamido)benzo[d][1,3]dioxol-5-yl)acrylate) 2a was selected to discuss, in succinct manner, the key signals from their ${ }^{1} \mathrm{H}$ and ${ }^{13} \mathrm{C}$ NMR spectra. Thus, with respect to the ${ }^{1} \mathrm{H}$ NMR spectrum (Figure 1a), there were two doublets at 7.72 and $6.21 \mathrm{ppm}$ with $J=15.7 \mathrm{~Hz}$, which were attributed to the trans-alkene system. Besides, with respect to the ${ }^{13} \mathrm{C}$ NMR spectrum (Figure 1b), there were two peaks at 172.0 and $166.9 \mathrm{ppm}$, which were attributed to both carbonyls (Figure 1b). 

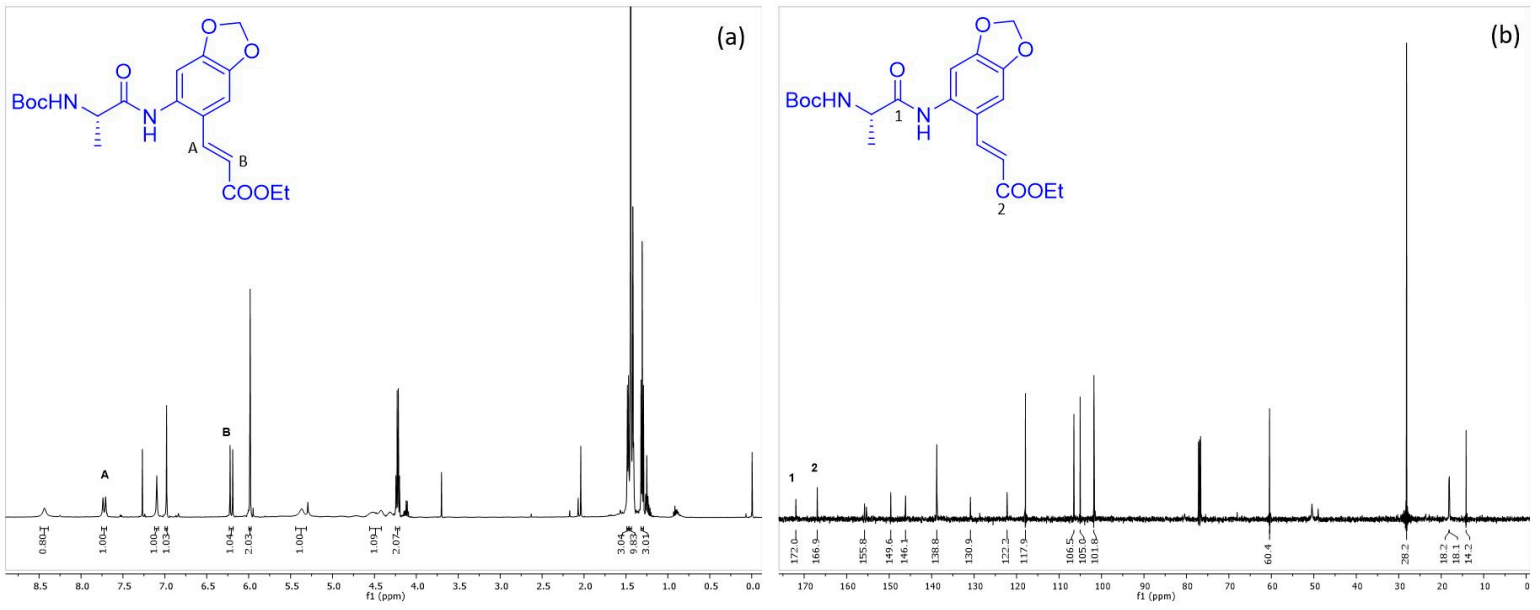

Figure 1. (a) ${ }^{1} \mathrm{H}$ NMR spectrum of the compound $2 \mathbf{a},(\mathbf{b}){ }^{13} \mathrm{C}$ NMR spectrum of the compound $2 \mathrm{a}$.

Currently, the first attempts using the chiral amine $\mathbf{2 a}$ as reagent in an Ugi-3CR are being performed. Thus, the amine $\mathbf{2 a}$ is first $\mathrm{N}$-Boc deprotected using trifluoroacetic acid (TFA) and then, combined sequentially with heptanaldehyde $\mathbf{3 a}$ and the chain-ring tautomerizable isocyanide to give the polyfunctionalized oxazole $9 \mathbf{a}$, which in turn may perform an aza Diels-Alder cycloaddition coupled to a further aromatization process to construct the peptide-containing macrocyclic structure 1a (Scheme 4). The results will be published soon.

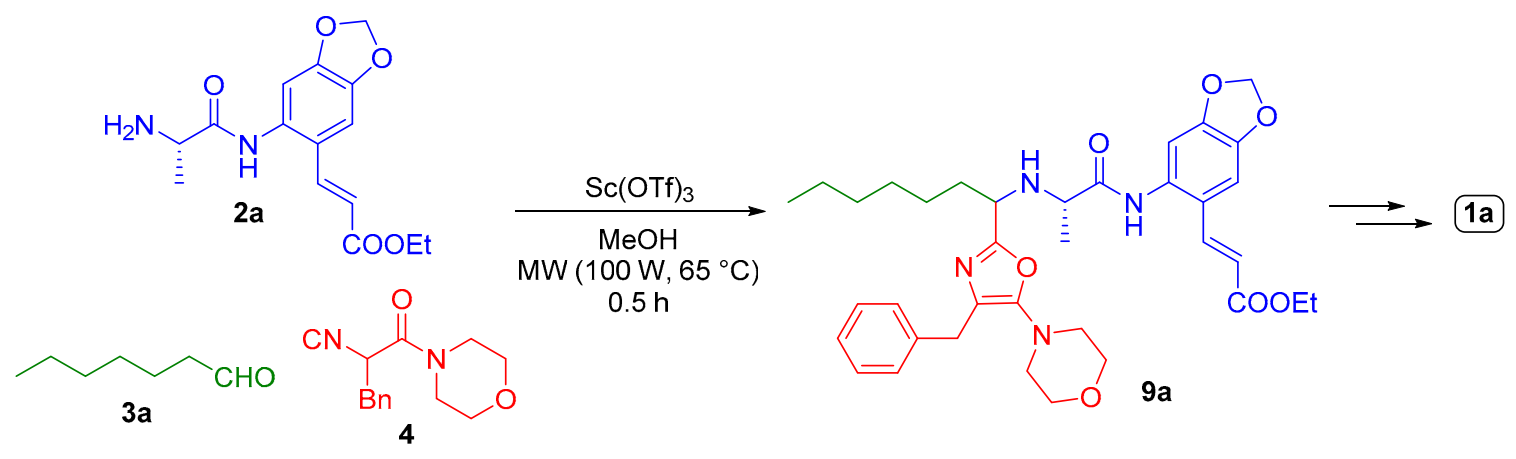

Scheme 4. Multicomponent reactions.

\section{Conclusions}

Four new exotic and polyfunctionalyzed $\alpha$ - $\beta$-unsaturated alkyl-ester chiral amines were synthesized in excellent yields (77-95\%) via peptidic couplings from their corresponding ortho-aminocinnamates and $\mathrm{N}$-Boc protected chiral aminoacids. The use of chiral and complex amines as starting reagents in MCRs toward macro-polyheterocyclic architectures is the main contribution of this work, which is a practically unexplored field in the MCR chemistry. To our delight, the first attempts are being performed, giving a product that seems to be an oxazole-based precursor of the desired peptide-containing macrocycles $\mathbf{1}$. 


\section{Experimental Part}

\subsection{General Information, Instrumentation and Chemicals}

${ }^{1} \mathrm{H}$ and ${ }^{13} \mathrm{C}$ NMR spectra were acquired on a Bruker Advance III (500 MHz) spectrometer. The solvent was deuterated chloroform $\left(\mathrm{CDCl}_{3}\right)$. Chemical shifts are reported in parts per million (ठ/ppm). Internal reference for NMR spectra is in respect to tetramethyl silane (TMS) at $0.0 \mathrm{ppm}$. Coupling constants are reported in Hertz $(\mathrm{J} / \mathrm{Hz})$. Multiplicities of the signals are reported using the standard abbreviations: singlet $(\mathrm{s})$, doublet $(\mathrm{d})$, triplet $(\mathrm{t})$, quartet $(\mathrm{q})$, and multiplet $(\mathrm{m})$. NMR data were treated using the MestReNova software (12.0.0-20080). IR spectra were acquired on a Perkin-Elmer series 1600 spectrophotometer. The absorbance peaks are reported in reciprocal centimeters $\left(\mathrm{cm}^{-1}\right)$. Elemental analyses were performed using a Cole-Palmer 2400 Series II. Reaction progress was monitored by TLC on precoated Kieselgel $60 \mathrm{~F}_{254}$ plates, and the spots were visualized under UV lights (254 or $365 \mathrm{~nm}$ ). Melting points were determined on a Fisher-Johns apparatus and are uncorrected. Structure drawings were done using the ChemDraw software (15.0.0.106). Mixtures of hexanes with ethyl acetate in 3:1 proportion $(v / v)$ were used as mobile phase to perform flash column chromatography. All starting materials were purchased from Sigma-Aldrich-Merck and used without further purification. The solvents were distilled and dried according to standard procedures. The N-Boc protections of amino acids [18] and chemoselective reductions of ortho-nitrocinnamates were carried out using classical reported conditions [19].

\subsection{Synthesis and Characterization of the $\alpha$ - $\beta$-Unsaturated Alkyl-Ester Chiral Amines 2a-d}

General Method: In a round-bottomed flask equipped with a magnetic stirring bar under inert atmosphere (Ar), 1.0 equiv. $(1.0 \mathrm{mmol})$ of the corresponding $N$-Boc protected aminoacids 5, 1.2 equivalent of $N$-(3-Dimethylaminopropyl)- $N$ '-ethylcarbodiimide hydrochloride (EDC), and 1.5 equivalent of hydroxybenzotriazole (HOBt) were added sequentially into $2 \mathrm{~mL}$ of anhydrous dichloromethane. After one hour, 1.0 equivalent of the corresponding ortho-aminocinnamates 6 was carefully added. The reaction mixture was stirred at room temperature for 92 hours keeping the inert atmosphere. Then, the reaction was stopped by adding $5 \mathrm{~mL}$ of a concentrated aqueous solution of sodium bicarbonate $\left(\mathrm{NaHCO}_{3}\right)$. Further extractions with dichloromethane $(3 \times 5 \mathrm{~mL})$ were performed, and the organic phase was collected, washed with brine, dried using anhydrous sodium sulfate, filtered over a celite pad, and concentrated to dryness under vacuum. The crude was purified by flash column chromatography using mixtures of hexanes with ethyl acetate (3:1 v/v) to afford the products $\mathbf{2} \mathbf{a}-\mathbf{d}$ as white solids.

Ethyl-(S,E)-3-(6-(2-((tert-butoxycarbonyl)amino)propanamido)benzo[d][1,3]dioxol-5-yl)acrylate (2a): yield $=77 \% ; \mathrm{mp}=144-146{ }^{\circ} \mathrm{C}$; IR $\left(\nu_{\max }\right)=3426,3012,3001,2348,2321,1788,1692,1603,1507,1494$, 1385, 1367, 1179, $1042 \mathrm{~cm}^{-1}{ }^{1}{ }^{1} \mathrm{H}$ NMR (500 MHz, $\left.\mathrm{CDCl}_{3}\right): \delta 8.43$ (bs, 1H), $7.72(\mathrm{~d}, J=15.4 \mathrm{~Hz}, 1 \mathrm{H}), 7.10$ $(\mathrm{s}, 1 \mathrm{H}), 6.98(\mathrm{~s}, 1 \mathrm{H}), 6.21(\mathrm{~d}, J=15.7 \mathrm{~Hz}, 1 \mathrm{H}), 5.99(\mathrm{~s}, 2 \mathrm{H}), 5.37(\mathrm{bs}, 1 \mathrm{H}), 4.55-4.41(\mathrm{~m}, 1 \mathrm{H}), 4.22(\mathrm{q}, J=$ $7.1 \mathrm{~Hz}, 2 \mathrm{H}), 1.48(\mathrm{~d}, J=7.0 \mathrm{~Hz}, 3 \mathrm{H}), 1.44(\mathrm{~s}, 9 \mathrm{H}), 1.31(\mathrm{t}, J=7.1 \mathrm{~Hz}, 3 \mathrm{H}) \mathrm{ppm} ;{ }^{13} \mathrm{C} \mathrm{NMR}(125 \mathrm{MHz}$, $\left.\mathrm{CDCl}_{3}\right): \delta 172.0,166.9,155.8,149.6,146.1,138.8,130.9,122.2,117.9,106.5,105.0,101.8,60.4,28.2,18.2$, 18.1, 14.2 ppm; Elem. Anal. calcd. for $\mathrm{C}_{20} \mathrm{H}_{26} \mathrm{~N}_{2} \mathrm{O}_{7}=\mathrm{C}(59.10), \mathrm{H}(6.45), \mathrm{N}(6.89 \%)$; found = C (57.74), $\mathrm{H}$ (6.71), N (6.61\%).

Ethyl-(S,E)-3-(6-(2-((tert-butoxycarbonyl)amino)-3-phenylpropanamido)benzo[d][1,3]dioxol-5-yl)acr ylate $(\mathbf{2 b})$ : yield $=95 \%$; $\mathrm{mp}=143-145^{\circ} \mathrm{C}$; IR $\left(v_{\max }\right)=3400,3005,2328,1800,1745,1516,1501,1474$, 1398, 1187, $1029 \mathrm{~cm}^{-1}$; ${ }^{1} \mathrm{H}$ NMR (500 MHz, CDCl $)$ : $\delta 7.73$ (bs, 1H), 7.54 (d, J = $\left.15.7 \mathrm{~Hz}, 1 \mathrm{H}\right), 7.34-7.30$ $(\mathrm{m}, 1 \mathrm{H}), 7.29-7.23(\mathrm{~m}, 1 \mathrm{H}), 7.09(\mathrm{~s}, 1 \mathrm{H}), 6.96(\mathrm{~s}, 1 \mathrm{H}), 6.18(\mathrm{~d}, J=15.7 \mathrm{~Hz}, 1 \mathrm{H}), 5.99(\mathrm{~s}, 2 \mathrm{H}), 5.10(\mathrm{bs}, 1 \mathrm{H})$, 4.54-4.49 (m, 1H), $4.23(\mathrm{q}, J=7.1 \mathrm{~Hz}, 2 \mathrm{H}), 3.24-3.13(\mathrm{~m}, 1 \mathrm{H}), 1.42(\mathrm{~s}, 9 \mathrm{H}), 1.31(\mathrm{t}, J=7.1 \mathrm{~Hz}, 3 \mathrm{H}) \mathrm{ppm}$; ${ }^{13} \mathrm{C}$ NMR $\left(125 \mathrm{MHz} \mathrm{CDCl}_{3}\right): \delta$ 170.3, 166.6, 155.7, 149.7, 146.2, 138.4, 136.4, 130.5, 129.3, 128.9, 127.2, 122.1, 118.8, 106.1, 105.4, 101.9, 60.5, 56.6, 38.1, 29.7, 28.2, 14.3 ppm; Elem. Anal. calcd. for $\mathrm{C}_{26} \mathrm{H}_{30} \mathrm{~N}_{2} \mathrm{O}_{7}$ $=\mathrm{C}(64.72), \mathrm{H}(6.27), \mathrm{N}(5.81 \%)$; found = C (64.97), H (7.02), N (5.49\%). 
Methyl-(S,E)-3-(2-(2-((tert-butoxycarbonyl)amino)propanamido)phenyl)acrylate $(2 \mathrm{c})$ : yield $=86 \%$; $\mathrm{mp}=145-147^{\circ} \mathrm{C} ; \mathrm{IR}\left(v_{\max }\right)=3450,2400,1792,1501,1456,1398,1245,1198,1003 \mathrm{~cm}^{-1} ;{ }^{1} \mathrm{H}$ NMR $(500$ $\left.\mathrm{MHz}, \mathrm{CDCl}_{3}\right): \delta 7.89-7.81(\mathrm{~m}, 2 \mathrm{H}), 7.55(\mathrm{~d}, J=7.9 \mathrm{~Hz}, 1 \mathrm{H}), 7.41-7.37(\mathrm{~m}, 1 \mathrm{H}), 7.22-7.18(\mathrm{~m}, 1 \mathrm{H}), 6.40$ $(\mathrm{d}, J=15.8 \mathrm{~Hz}, 1 \mathrm{H}), 5.07-5.01(\mathrm{~m}, 1 \mathrm{H}), 4.40-4.29(\mathrm{~m}, 1 \mathrm{H}), 3.81(\mathrm{~s}, 3 \mathrm{H}), 1.50-1.49(\mathrm{~m}, 12 \mathrm{H}) \mathrm{ppm} ;{ }^{13} \mathrm{C}$ NMR (125 MHz, CDCl3): $\delta$ 177.2, 162.6, 155.6, 139.7, 130.8, 127.2, 125.8, 124.5, 120.4, 113.1, 111.8, 65,1, 51.8, 49.1, 28.3, 18.3 ppm; Elem. Anal. calcd. for $\mathrm{C}_{18} \mathrm{H}_{24} \mathrm{~N}_{2} \mathrm{O}_{5}=\mathrm{C}(62.05), \mathrm{H}(6.94), \mathrm{N}(8.04 \%)$; found = C (61.85), H (6.30), N (8.18\%).

Methyl-(S,E)-3-(2-(2-((tert-butoxycarbonyl)amino)-3-phenylpropanamido)phenyl)acrylate $\quad$ (2d): yield $=94 \% ; \mathrm{mp}=133-135{ }^{\circ} \mathrm{C}$; IR $\left(\nu_{\max }\right)=3452,3012,2412,1802,1699,1521,1504,1498,1386,1234$, $1000 \mathrm{~cm}^{-1}$; ${ }^{1} \mathrm{H}$ NMR $\left(500 \mathrm{MHz}, \mathrm{CDCl}_{3}\right): \delta 7.90$ (bs, $\left.1 \mathrm{H}\right), 7.75(\mathrm{~d}, J=8.2 \mathrm{~Hz}, 1 \mathrm{H}), 7.64(\mathrm{~d}, J=15.8 \mathrm{~Hz}, 1 \mathrm{H})$, $7.51(\mathrm{~d}, J=7.3 \mathrm{~Hz}, 1 \mathrm{H}), 7.39-7.35(\mathrm{~m}, 1 \mathrm{H}), 7.34-7.23(\mathrm{~m}, 4 \mathrm{H}), 7.22-7.17(\mathrm{~m}, 2 \mathrm{H}), 6.33(\mathrm{~d}, J=15.8 \mathrm{~Hz}$, 1H), 5.16-5.09 (m, 1H), 4.60-4.51 (m, 1H), $3.81(\mathrm{~s}, 3 \mathrm{H}), 3.23-3.14(\mathrm{~m}, 2 \mathrm{H}), 1.43(\mathrm{~s}, 3 \mathrm{H}) \mathrm{ppm} ;{ }^{13} \mathrm{C}$ NMR (125 MHz, $\left.\mathrm{CDCl}_{3}\right): \delta 174.8,170.5,167.0,155.8,139.6,136.5,135.5,130.7,129.5,129.3,128.8,128.4$, $127.2,127.1,125.9,124.5,120.4,56.7,51.8,38.3,37.9,28.2$ ppm; Elem. Anal. calcd. for $\mathrm{C}_{24} \mathrm{H}_{28} \mathrm{~N}_{2} \mathrm{O}_{5}=\mathrm{C}$ (67.91), H (6.65), N (6.60\%); found = C (66.79), H (6.87), N (6.30\%).

Author Contributions: All authors contributed equally to this work.

Acknowledgments: O.V.-K. thanks CONACyT for his scholarship (819242). D.A.deL. thanks CONACyT (CB-2013-220844) for the financial support. L.L.-R. acknowledges CONACyT-México (CB-2016-255819) and PRODEP (fortalecimiento de CA's) for the financial support. I.A.I. acknowledges PAPIIT-UNAM-Mexico (IN101517) and CONACYT (1789) for the financial support. A.I-J. acknowledges QI-DQ-CBI-UAMI for his visiting professor position (40966) and PRODEP-SEP for the financial support (12413143). E.G.-Z. thanks CONACyT (CB-2014-236879) for the financial support.

Conflicts of Interest: The authors declare no conflict of interest. The funders had no role in the design of the study; in the collection, analyses, or interpretation of data; in the writing of the manuscript, or in the decision to publish the results.

\section{References}

1. Ramón, D.J.; Yus, M. Asymmetric Multicomponent Reactions (AMCRs): The New Frontier. Angew. Chem. Int. Ed. 2005, 44, 1602-1634, doi:10.1002/anie.200460548.

2. Ruijter, E.; Scheffelaar, R.; Orru, R.V.A. Multicomponent Reaction Design in the Quest for Molecular Complexity and Diversity. Angew. Chem. Int. Ed. 2011, 50, 6234-6246, doi:10.1022/anie.201006515.

3. Dömling, A.; Ugi, I. Multicomponent Reactions with Isocyanides. Angew. Chem. Int. Ed. 2000, 39, 3168-3210.

4. Oh, S.; Park, S.B. A design strategy for drug-like polyheterocycles with privileged substructures for discovery of specific small-molecule modulators. Chem. Commun. 2011, 47, 12754-12761, doi:10.1039/c1cc14042f.

5. Ulaczyk-Lesanko, A.; Hall, D.G. Wanted: New multicomponent reactions for generating libraries of polycyclic natural products. Curr. Opt. Chem. Biol. 2005, 9, 266-276, doi:10.1016/j.cbpa.2005.04.003.

6. Biggs-Houck, J.E.; Younai, A.; Shaw, J.T. Recent advances in the multicomponent reactions for diversity-oriented synthesis. Curr. Opt. Chem. Biol. 2010, 14, 371-382, doi:10.1016/j.cbpa.2010.03.003.

7. Cao, H.; Liu, H.; Dömling, A. Efficient Multicomponent Reaction Synthesis of the Schistosomiasis Drug Praziquantel. Chem. Eur. J. 2010, 16, 12296-12298, doi:10.1002/chem.201002046.

8. Ibarra, I.A.; Islas-Jácome, A.; González-Zamora, E. Synthesis of polyheterocycles via multicomponent reactions. Org. Biomol. Chem. 2008, 16, 1402-1418, doi:10.1039\%c7ob02305g.

9. Bughin, C.; Masson, G.; Zhu, J. Rapid Synthesis of Cyclodepsipeptides Containing a Sugar Amino Acid or a Sugar Amino Alcohol by a Sequence of a Multicomponent Reaction and Acid-Mediated Macrocyclization. J. Org. Chem. 2007, 72, 1826-1829, doi:10.1021/jo0621874.

10. Zhu, J. Recent Developments in the Isonitrile-Based Multicomponent Synthesis of Heterocycles. Eur. J. Org. Chem. 2003, 1133-1144, doi:10.1002/ejoc.200390167.

11. Failli, A.; Immer, H.; Götz, M. The synthesis of cyclic peptides by the four component condensation (4 CC). Can. J. Chem. 1979, 57, 3257-3261. 
12. Chavez-Acevedo, L.; Miranda, L.D. Synthesis of novel tryptamine-based macrocycles using an Ugi 4-CR/microwave assisted click-cycloaddition reaction protocol. Org. Biomol. Chem. 2015, 13, 4408-4412, doi:10.1039/c5ob00067j.

13. Vázquez-Vera, O.; Sánchez-Badillo, J.S.; Islas-Jácome, A.; Rentería-Gómez, M.A.; Pharande, S.G.; Cortes-García, C.J.; Rincón-Guevara, M.A.; Ibarra, I.A.; Gámez-Montaño, R.; González-Zamora, E. An efficient Ugi-3CR/aza Diels-Alder/Pomeranz-Fritsch protocol towards novel aza-analogues of $( \pm)$-nuevamine, $( \pm)$-lennoxamine and magallanesine: A diversity oriented synthesis approach. Org. Biomol. Chem. 2017, 15, 2363-2369, doi:10.1039/c6ob02572b.

14. Islas-Jácome, A.; González-Zamora, E.; Gámez-Montaño, R. A short microwave-assisted synthesis of tetrahydroisoquinolinpyrrolopyridinones by a triple process: Ugi-3CR-aza Diels-Alder/S-oxidation/Pummerer. Tetrahedron Lett. 2011, 52, 5245-5248, doi:10.1016/j.tetlet.2011.07.134.

15. González-Zamora, E.; Fayol, A.; Bois-Choussy, M.; Chiaroni, A.; Zhu, J. Three component synthesis of oxa-bridged tetracyclic tetrahydroquinolines. Chem. Commun. 2001, 1684-1685, doi:10.1039/b104317j.

16. Fayol, A.; González-Zamora, E.; Bois-Choussy, M.; Zhu, J. Lithium Bromide-Promoted Three-Component Synthesis of Oxa-Bridged Tetracyclic Tetrahydroisoquinolines. Heterocycles 2007, 73, 729-742, doi:10.3987/COM-07-S(U)54.

17. Vázquez-Vera, O.; Segura-Olvera, D.; Rincón-Guevara, M.A.; Gutierrez-Carrillo, A.; García-Sánchez, M.A.; Ibarra, I.A.; Lomas-Romero, L.; Islas-Jácome, A.; González-Zamora, E. Synthesis of New 5-Aryl-benzo[f] [1,7]naphthyridines via a Cascade Process (Ugi-3CR/Intramolecular Aza-Diels-Alder Cycloaddition)/ Aromatization. Molecules 2018, 23, 2029, doi:10.3390/molecules23082029.

18. Ragnarsson, U.; Grehn, L. Dual protection of amino functions involving Boc. RSC Adv. 2013, 3, 18691-18697, doi:10.1039/c3ra42956c.

19. Li, H.; Yang, J.; Porter, N.A. Preparation and photochemistry of o-aminocinnamates. J. Photochem. Photobiol. A Chem. 2005, 169, 289-297, doi:10.1016/j.jphotochem.2004.06.021.

(C) 2018 by the authors. Licensee MDPI, Basel, Switzerland. This article is an open access article distributed under the terms and conditions of the Creative Commons Attribution (CC BY) license (http://creativecommons.org/licenses/by/4.0/). 